\title{
Control of Deep Currents on Sediment and Cold-Water Coral Distribution on the Northern Manihiki Plateau
}

\author{
Sara Bashah ${ }^{1 *}$, Kimberly C. Galvez ${ }^{1}$, Gregor P. Eberli ${ }^{1}$ and Kasey Cantwell2,3 \\ ' Comparative Sedimentology Laboratory - Center for Carbonate Research, Rosenstiel School for Marine and Atmospheric \\ Science, University of Miami, Miami, FL, United States, ${ }^{2}$ Office of Ocean Exploration and Research, National Oceanic \\ and Atmospheric Administration, U.S. Department of Commerce, Silver Spring, MD, United States, ${ }^{3}$ Cherokee Nation \\ Strategic Programs, Arlington, VA, United States
}

\section{OPEN ACCESS}

Edited by:

Jose Angel Alvarez Perez, Universidade do Vale do Itajaí, Brazil

Reviewed by:

Tina Molodtsova

P.P. Shirshov Institute of Oceanology

(RAS), Russia

lan David Tuck,

National Institute of Water and Atmospheric Research (NIWA),

New Zealand

*Correspondence: Sara Bashah

nbashah@rsmas.miami.edu

Specialty section:

This article was submitted to Deep-Sea Environments and Ecology, a section of the journal

Frontiers in Marine Science

Received: 15 June 2019

Accepted: 08 April 2020

Published: 05 May 2020

Citation:

Bashah S, Galvez KC, Eberli GP and Cantwell K (2020) Control of

Deep Currents on Sediment and Cold-Water Coral Distribution on the

Northern Manihiki Plateau.

Front. Mar. Sci. 7:288

doi: 10.3389/fmars.2020.00288
High-definition video surveys of remotely-operated vehicle (ROV) dives from the NOAA's Mountains in the Deep 2017 expedition (EX1705) along volcanic ridges and seamounts of the Manihiki Plateau coupled with multibeam bathymetry data and water column profiles, reveal no or minimal sediment cover on the basaltic edifice, but variable amounts of cold-water corals on ferromanganese-encrusted basaltic rocks. Coarse sediment, however, accumulates in crevasses and sedimentary ripples testify the existence of currents in the area. Collectively, these observations illustrate the strong influence of deep currents on the surficial geology and cold-water coral distribution at $\sim 2,000 \mathrm{~m}$ water depths. Dive transects along two basaltic seamounts show stark differences of sedimentary features and cold-water coral distribution. On the ridges of "Te Kawhiti" (water depth: 2,089-2,220 m), basaltic slabs, and cold-water corals are far more abundant in comparison to the slope of a mesa in "Te Tuku" (water depth: 2,440-2,495 m). The increased abundance on "Te Kawhiti" is due to the exposure of "Te Kawhiti" to Lower Circumpolar Deep Water that sweeps the summit of the ridges as indicated by frequent ripples observed in between the basaltic rocks. The currents are strong enough to sweep fine-grained sediments away, leaving coarsegrained sediments behind, inducing the formation of ferromanganese crust on the basaltic rocks. Both dive sites are below the high-Mg calcite saturation horizon, and as a result, the cold-water coral community is dominated by Isididae, which can build a high-Mg calcite skeleton in water undersaturated in regards to high-Mg calcite.

Keywords: seamounts, current deposits, cold-water corals, high-Mg calcite saturation horizon, Lower Circumpolar Deep Water

\section{INTRODUCTION}

Seamounts are isolated topographic elevations with summit depths at least $1,000 \mathrm{~m}$ above the seafloor, which includes large plateaus and platforms. Seamounts have a significant effect on circulation patterns and currents locally and regionally, influencing the morphology and sedimentology of the surrounding seafloor (Batiza, 2001; Rogers, 2013). On seamounts, sediments accumulate from settling particles through the water column, forming a drape of pelagic ooze. The Manihiki Plateau formed by volcanic activity approximately 125 million years ago as part of the 
giant Ontong Java-Manihiki-Hikurangi plateau in the Pacific Ocean (Pietsch and Uenzelmann-Neben, 2015; Timm et al., 2011). The sediment accumulation rate at the Manihiki Plateau is $10 \mathrm{~m} / \mathrm{million}$ year and, in some areas in the deep troughs, up to $1 \mathrm{~km}$ of sediments were accumulated due to redeposition of plateau sediments by slumps and turbidity currents (Winterer et al., 1974). In other areas, however, the seamounts consist of bare basaltic rocks with little to no sediment cover, indicating that sediment falling through the water column is swept off the basaltic edifice by deep ocean currents.

This study focuses on two such areas along the Northern Manihiki Plateau surveyed during the Mountains in the Deep 2017 expedition (EX1705) - the slope of the "Te Tuku" mesa and the summit of "Te Kawhiti" ridges. These sites were selected from the National Oceanic and Atmospheric Administration's Campaign to Address Pacific monument Science, Technology, and Ocean NEeds (CAPSTONE; Kennedy et al., 2019). We rely on multibeam bathymetry, conductivity, temperature, and depth (CTD) data, and remotely-operated vehicle (ROV) video footage to show the influence of currents conditions on the sediment accumulation and Isididae occurrences in water depths below the high-Mg calcite saturation horizon (HMCSH). Isididae or "bamboo-corals" are octocorals characterized by their calcite internodes alternating with organic nodes skeletal arrangements, resembling bamboo plants (Grant, 1976; France, 2007). The calcitic part of the skeleton are made of high-Mg calcite fibers and granular crystals which are precipitated from the surrounding seawater dissolved inorganic carbon (Roark et al., 2005; Noé and Dullo, 2006).

We map the seafloor facies and fauna along two dive transects with the goal of investigating the relationship between the sediments and Isididae distribution with the current conditions in the Northern Manihiki Plateau. Observations from the ROV also document a viable community of Isididae found below $2,000 \mathrm{~m}$ on a seamount-ridge. We further outline possible processes of how the isidids can precipitate their skeleton in the high-Mg calcite undersaturated seawater.

\section{STUDY AREA}

The Manihiki Plateau is a $\sim 600,000 \mathrm{~km}^{2}$ section of elevated ocean floor in the western equatorial Pacific Ocean (Figure 1A), surrounded by approximately 6-km-deep basins, which include the Penrhyn Basin to the east, Samoan Basin to the southwest, Tokelau Basin to the northwest, and the Central Basin of the Pacific to the north (Heezen et al., 1966; Winterer et al., 1974). The Lower Circumpolar Deep Water (LCDW), which enters the Pacific basin southeast of New Zealand as a deep western boundary current and flows northward, touches the Manihiki Plateau and the two dive sites (Figure 1B; Kawabe and Fujio, 2010). "Te Tuku" is located at the leeward of the LCDW, while "Te Kawhiti" is located facing the LCDW flow direction. Within the water masses of the southwest Pacific are levels of chemical concentrations in seawater that directly affect the surrounding environment. The aragonite saturation horizon $(\mathrm{ASH})$ and the calcite saturation horizon $(\mathrm{CSH})$ fall under this category. Below the ASH is the depth at which the seawater becomes undersaturated with respect to aragonite. The $\mathrm{CSH}$ is similar to the ASH, except it is for all calcite concentrations; usually, the CSH is at a greater depth than that of the ASH due to the increased solubility of aragonite. The ASH in the Southwest Pacific is $\sim 200$ to $1,320 \mathrm{~m}$ (Feely et al., 2002), while the CSH is at $\sim 2,800 \mathrm{~m}$ water depth (Feely et al., 2002; Bostock et al., 2011). The solubility of high-Mg calcite is similar to or slightly higher than aragonite, which is between 1 and $1.5 \mathrm{~km}$ (Morse et al., 2006). Calcifying organisms that use carbonate concentrations in seawater to produce their skeletons are limited to depths that are above the ASH or CSH, respectively (Feely et al., 2002).

\section{MATERIALS AND METHODS}

Bathymetric data, ROV videos and images, and CTD data were used from two dives in the Northern Manihiki Plateau at sites named in consultation with the Office of the Prime Minister in the Cook Islands and Ui Ariki Ngateteitei o Te Kuki Airani (The Paramount Kings and Queens of the Cook Islands) "Te Tukunga o Fakahotu" ("Te Tuku”) and "Te Kawhiti a Maui Potiki" (“Te Kawhiti”). The two dives were conducted using the ROV Deep Discoverer and a camera and lighting platform, ROV Seirios. The ROVs captured high-definition videos, collected both biological and geological samples, and measured parameters such as salinity, water temperature, depth, and dissolved oxygen using on-board sensors. The "Te Tuku" dive (Dive 02) was conducted from 2,440 to 2,495 m, and the “Te Kawhiti" dive (Dive 03) from 2,089 to 2,220 m. The seafloor bathymetry was mapped using a Kongsberg EM302 multibeam system and analyzed using Fledermaus software (Figures 1C,D). Conductivity, temperature, and depth measurements from the ROV determined general water mass characteristics and the influence of physical parameters of water masses (Figures 1E,F). Current measurements were conducted with an acoustic doppler current profiler (ADCP) mounted to the ship measuring currents in the top $600 \mathrm{~m}$ of the water column and, thus, did not provide information at study sites more than $2 \mathrm{~km}$ deep. However, the direction of the ripples observed at the dive sites are in concert with the direction of current measured from ADCP. Cold-water corals and associated surficial sedimentary facies distribution were analyzed from the ROV videos and images (Cantwell et al., 2017). The mapping of the cold-water corals focuses on the distribution of the Isididae as their skeleton is made up of high-Mg calcite.

\section{RESULTS}

\section{Bathymetric Settings of the Dives Location}

The elongated mesa of "Te Tuku" is $82 \mathrm{~km}$-long, $15 \mathrm{~km}$-wide, and $2,300 \mathrm{~m}$-tall. The mesa shows a tapered shape with the northwest end being the widest section and narrowing to the southeast. The dive on the eastern slope of the mesa moved up the slope from 2,495 to $2,440 \mathrm{~m}$ water depth, covering roughly $60 \mathrm{~m}$ of water 

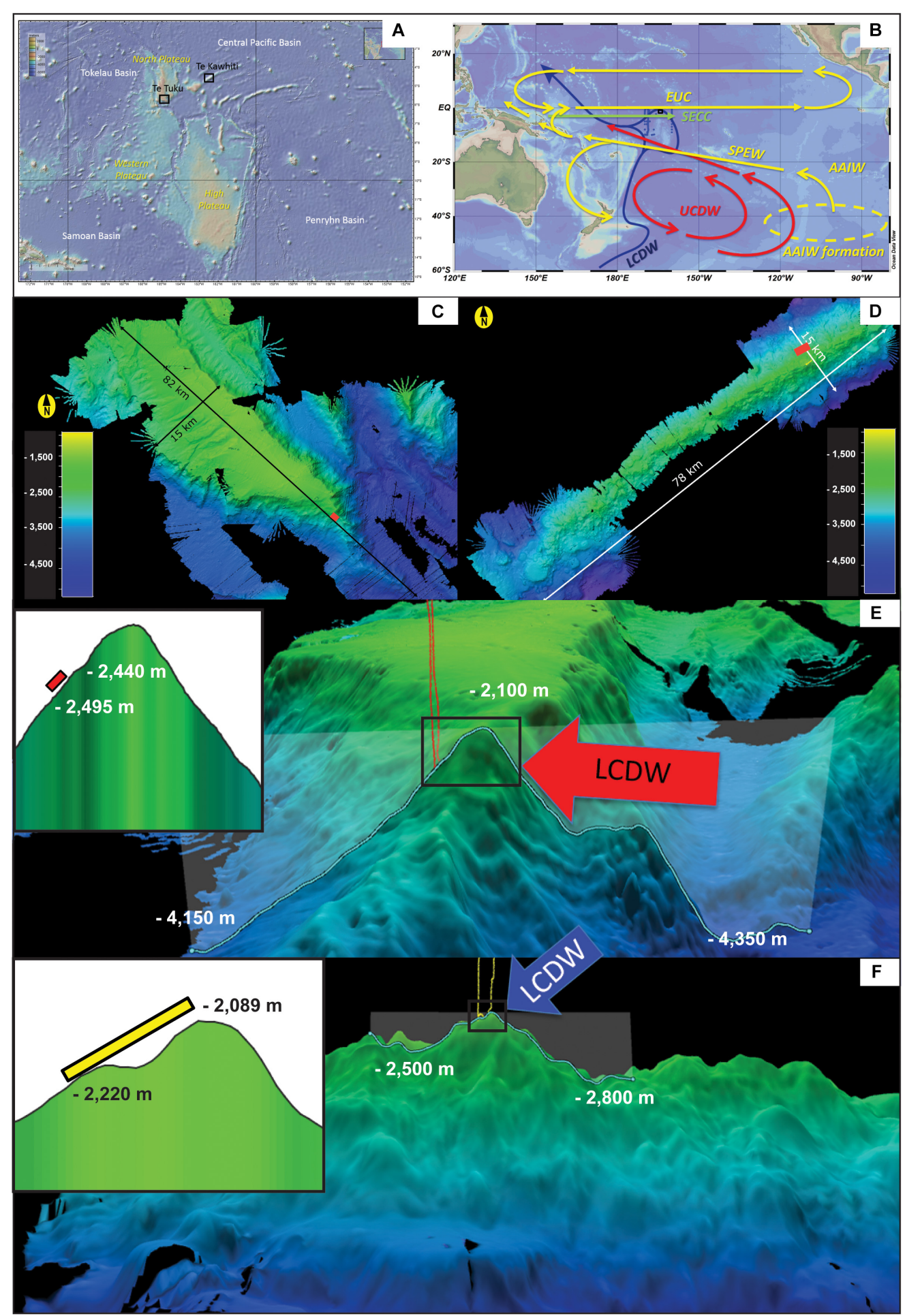

FIGURE 1 | (A) Map of the Northern Manihiki Plateau displaying ROV dives location in black boxes. Plateau regions are labeled in yellow and basins are in white. (B) Map from Ocean Data View showing main circulation patterns and directions (according to Kawabe and Fujio, 2010 and Werner et al., 2013) are displayed with green arrows (<1,000 m water depth) yellow arrows (1,000-1,500 m water depth), red arrows (1,500-3,000 m water depth), and blue arrows (bottom water, $>3,000 \mathrm{~m}$ water depth). Yellow oval indicates the AAIW formation region. Water masses in the area are AAIW, Antarctic Intermediate Water; UCDW, Upper Circumpolar Deep Water; LCDW, Lower Circumpolar Deep Water; SPEW, South Pacific Equatorial Water; EUC, Equatorial Undercurrent and SECC: south Equatorial Counter Current (modified from Molina-Kescher et al., 2018). Blue dots represent CTD data available from the World Ocean Database (Boyer et al., 2018).

(C) Bathymetry of the "Te Tuku" mesa. (D) Bathymetry of the "Te Kawhiti" ridges. (E) Cross-section of the mesa at "Te Tuku" with dive transect (black box) and LCDW direction (red arrow). (F) Cross-section of seamounts summit at Te Kahwiti with dive transect marked in black box LCDW direction (blue arrow). 
depth. The slope angles of the dive transect range from $12^{\circ}$ to $22^{\circ}$ (Figures 1C,E).

The Te Kawhiti ridge is $78 \mathrm{~km}$-long, $17 \mathrm{~km}$-wide, and 2,300 mtall with a series of peaks. The dive began on the southwest side of the ridge, following the slope upward, then along the crest of the ridge for $160 \mathrm{~m}$ reaching the summit of a local high point on the ridge crest. The slope angles at the dive sites ranged from $-3^{\circ}$ to $23^{\circ}$ (Figures 1D,F).

\section{Physical Water Mass Properties}

Different water masses exist in the Manihiki Plateau area based on the temperature-salinity (T-S) plot from the ROV CTD and CTD data from Boyer et al. (2018). From the surface down, the water masses are the South Equatorial Counter Current (SECC), the Equatorial Undercurrent (EUC), Antarctic Intermediate Water (AAIW), South Pacific Equatorial Water (SPEW), Upper Circumpolar Deep Water (UCDW), and LCDW. Both dive locations are located in the range of the LCDW (Tomczak and Godfrey, 2003; Kawabe and Fujio, 2010; Hartin et al., 2011; Figures 2A1,2).

The vertical profiles of the ROV CTD show that throughout the dives, the LCDW temperature varied between 1.5 and $2.5^{\circ} \mathrm{C}$, with average temperatures at "Te Kawhiti" warmer by $1^{\circ} \mathrm{C}$ than at "Te Tuku." The salinity recorded throughout both dives were quite uniform at 34.5 PSU. Oxygen saturation at "Te Tuku" ranged from 125 to $130 \mu \mathrm{mol} / \mathrm{kg}$ but was uniform at $116 \mu \mathrm{mol} / \mathrm{kg}$ at "Te Kawhiti" (Figures 2B1,2). Both dives are located below the HMCSH (Figure 2B). Assuming that the current at 2,000$2,500 \mathrm{~m}$ is in the same direction as measured with ADCP at $600 \mathrm{~m}$, the "Te Tuku" dive is located on the "leeward" side of the northeast bottom current flow. At "Te Kawhiti," where the dive path is perpendicular to the south-flowing LCDW (Figure 2A3).

\section{Video Footage-Based Mapping}

The video footage from ROV Deep Discoverer reveals the basaltic basement, some sediment coverage, and a variable amount of cold-water corals. The facies of the seascape is divided into eight groups: basaltic cobbles, boulders and slabs, coarse sands, coral debris, ripples, living single Isididae, and living Isididae thickets (Figure 3).

\section{"Te Tuku"}

Figure $4 \mathrm{~A}$ displays the distribution of the basaltic basement, sediments, and Isididae along the dive path at "Te Tuku." The substrate along this dive consists only of cobbles and boulders. Coarse sediments fill the depressions in between these substrates, but the sediments do not cover the cobbles and boulders. Asymmetric ripples in coarse sand layers were observed only once at 2,455 $\mathrm{m}$ water depth. Living single Isididae are found at 2,440, 2,460 , and 2,490 $\mathrm{m}$ water depths.

\section{"Te Kawhiti"}

Figure 4B displays the distribution of the basaltic basement, sediments, and Isididae along the dive path at "Te Kawhiti." The substrate observed along this dive consists of cobbles, boulders, and basaltic slabs. Coarse sediments fill the depressions in between the substrates and covers them. Ripple structures are present frequently along the dive path, except on the steeper slope toward the summit of the ridge. Isididae thrive as thickets along the dive except at 2,220 $\mathrm{m}$ water depth. Here, the Isididae live as singles between coarse sands and coral debris. Coral debris is sparse but is observed at 2,160 and 2,135 m water depths.

\section{Difference Between the Two Sites}

Although the morphology of the "Te Tuku" mesa and the "Te Kawhiti" ridges are different, the bedrock at both locations is composed of ferromanganese-encrusted basaltic rocks. The slope of the "Te Tuku" mesa consists of scattered basaltic cobbles and boulders lying exposed on soft sediments with depressions infilled with trapped sediment (Figures 3A,B). In contrast, the ridges of "Te Kawhiti" are dominated by large basaltic slabs that exhibit a smooth surface with small crevices infilled with sediment (Figure 3C).

Three main sediment features are observed: coarse sands, ripples, and rare coral debris. Coarse sands, likely consisting of foraminifera and ossicles of carbonate-secreting organisms, are deposited between the basaltic boulders and cobbles (Figure 3D). Little to no sediment accumulates on top of the boulders. The carbonate sands sometimes form small, symmetric current ripples between the boulders (Figure $\mathbf{3 H}$ ). In one area at "Te Kawhiti," the ripples are arranged in a fan-like pattern, indicating that a strong current that is deflected by the topography of the seamounts. There is a stark contrast of sediment distribution in both dives; the "Te Tuku" site has a large abundance of coarse sands with no ripples and no occurrence of coral debris. At "Te Kawhiti," sediments show an abundance of ripples, some coral debris, but lack the coarse sand (Figures 3, 4).

Among various types of biota observed, cold-water corals were abundant. The identification of coral species based solely on video footage is difficult, but based on the combined observations of onboard and shore-based EX1705 deep-sea biologists, cold-water corals along the dives include Isididae, Paragorgia, Zoantharia, and Antipatharia. As with the sediments and substrates, we observed a significant contrast in Isididae occurrences. At the slope of the "Te Tuku" mesa, solitary Isididae corals live on the basaltic cobbles and boulders. No coral thickets were observed. In contrast, Isididae thickets thrive and are well-distributed along the summit of the ridge at "Te Kawhiti" from 2,089 to 2,220 m depth (Figures 3F, 4B). Many of these thickets are taller than the ROV Deep Discoverer (2.6 m tall). In areas with coarse mobile sands, generally no corals were observed, but few living single Isididae and coral debris were found at depths greater than 2,200 $\mathrm{m}$ (Figure 4).

\section{DISCUSSION}

\section{Sedimentological Features as Indicators of Current Strength and Direction}

At the two sites, there is a stark contrast in the distribution of coarse carbonate sand. The coarse sand layers at "Te Tuku" have asymmetric ripples that indicate a southward direction of the current. Ripples in such coarse-grained sediments are formed by currents, with a strength that likely reaches up to $0.5 \mathrm{~m} / \mathrm{s}$ 


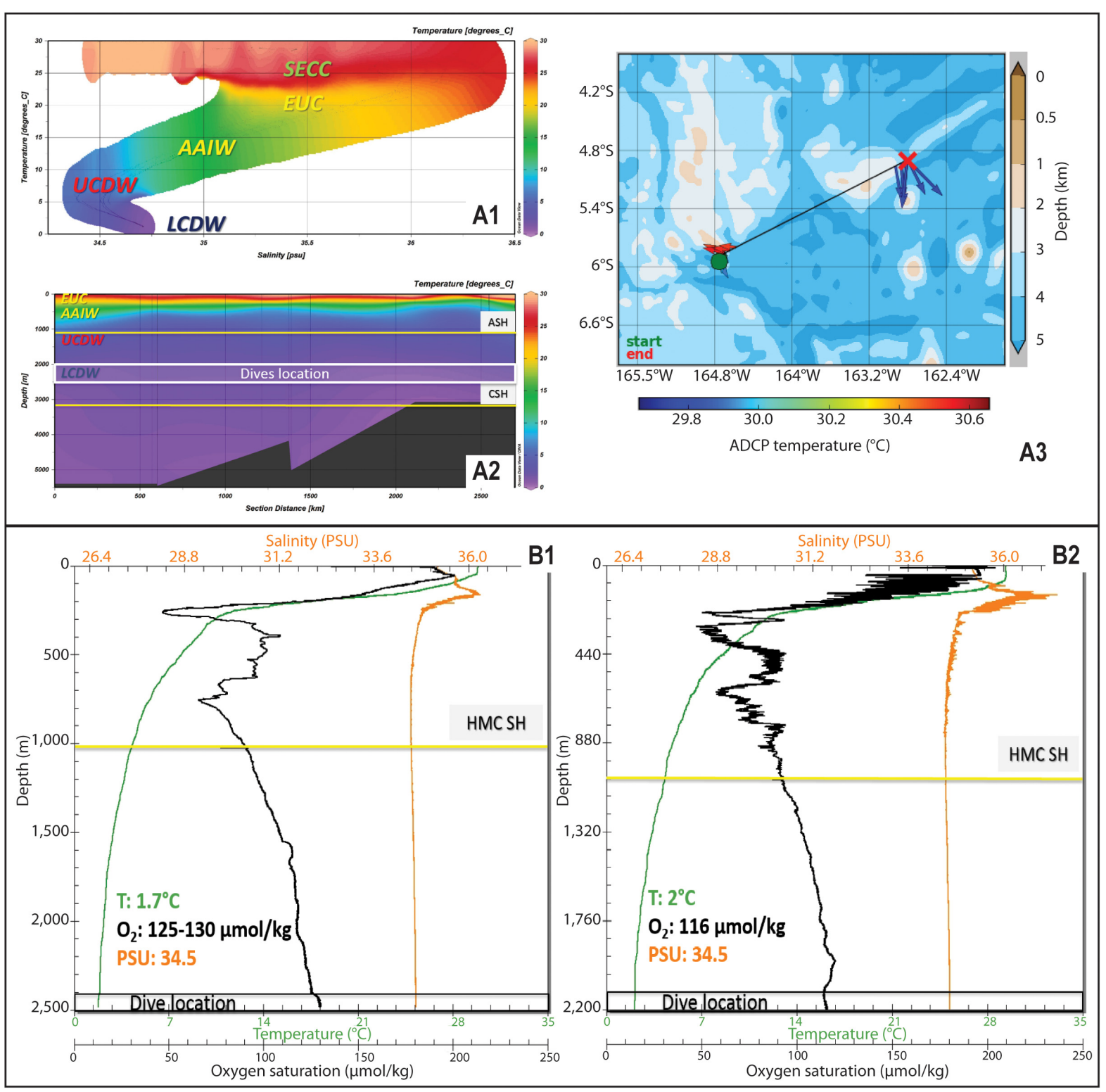

FIGURE 2 | Current data at the dives transect (A1) Temperature-salinity diagram with water masses identified. AAIW, Antarctic Intermediate Water; UCDW, Upper Circumpolar Deep Water; LCDW, Lower Circumpolar Deep Water; SPEW, South Pacific Equatorial Water; EUC, Equatorial Undercurrent, and SECC, South Equatorial Counter Current. (A2) Water masses across the water depths. The dives depths are within the LCDW (white box). Yellow lines indicate the approximate depths of the aragonite saturation horizon (ASH) and calcite saturation horizon (CSH). (A3) Current direction of the top $600 \mathrm{~m}$, collected from ADCP during EX1705. The red arrows give the temperature and shallow water current direction in "Te Tuku." The blue arrows give the temperature and shallow water current direction in "Te Kawhiti." (B1) and (B2) are ROV CTD temperature (green lines), oxygen saturation (black lines), and salinity (orange lines) profiles of "Te Tuku" dive (B1) and "Te Kawhiti" dive (B2). High-Mg calcite saturation horizon (HMCSH) is indicated with yellow lines. Rectangular boxes at the bottom of the graphs show the dive locations.

(Stow et al., 2009; Figures 3H, 4B). The limited occurrence of sand and ripples at "Te Kawhiti" implies even stronger currents on the summit of the ridges, which inhibit the deposition of sediments, causing the formation of ferromanganese crust on the basaltic rocks. The fact that the 125 million years old basaltic seamounts are not covered by sediment or diagenetically altered limestone implies that currents were sweeping the study site since their formation. The acting currents must have changed through time as the Manihiki Plateau moved with the plates in the Pacific (Winterer et al., 1974). Currents in the Pacific also change through time due to the combined result of the closure of the Tethys seaway 80 million years ago and the concomitant mixing of Atlantic and Pacific waters (Stille, 1992) and the onset of Antarctic Circumpolar Current in the Oligocene (Lyle et al., 2007). Despite these changes and the resulting changes in the strength of the current, no relict sediment beds or limestone caps were observed during the dives, indicating a permanent, strong current system at 2,000 $\mathrm{m}$ water depth in the Pacific 


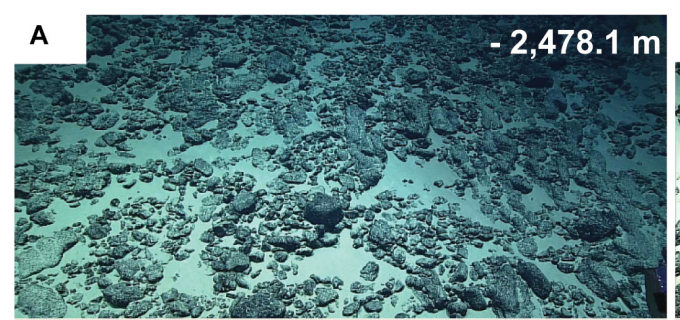

Basaltic cobbles

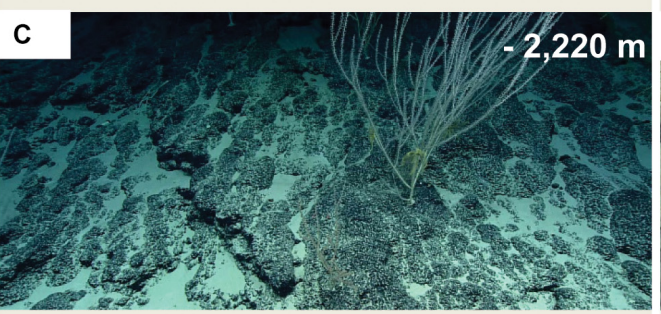

Basaltic slabs

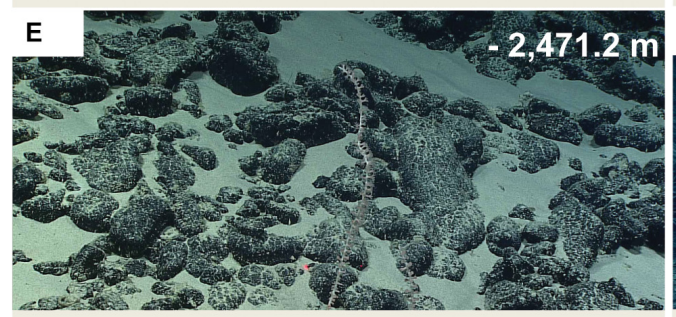

Living single Isididae

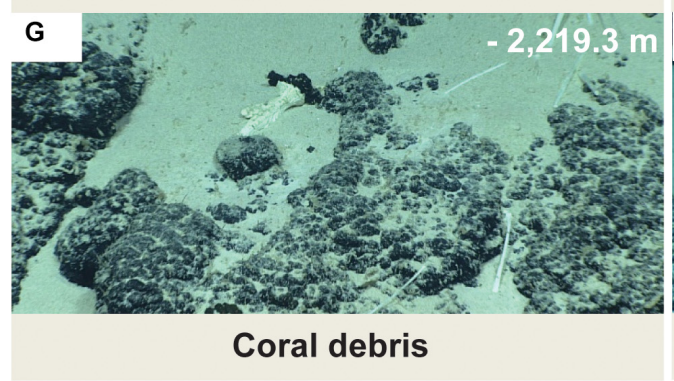

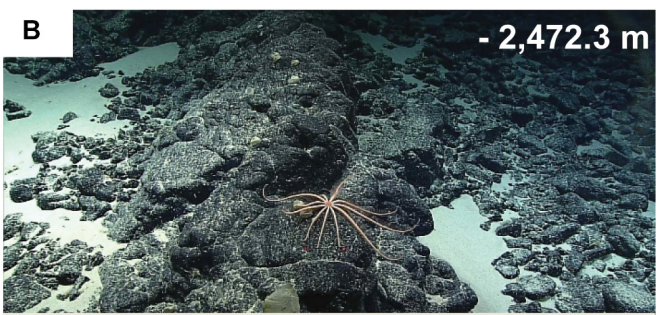

Basaltic boulder

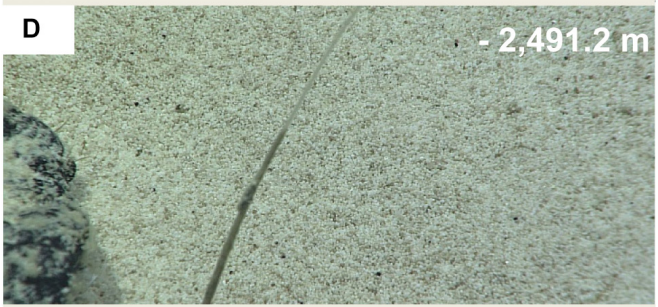

Coarse sands

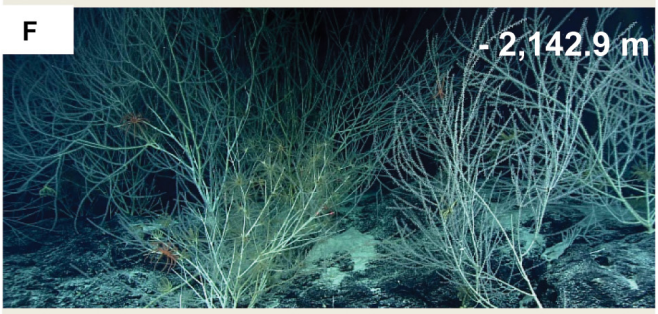

Living Isididae thickets

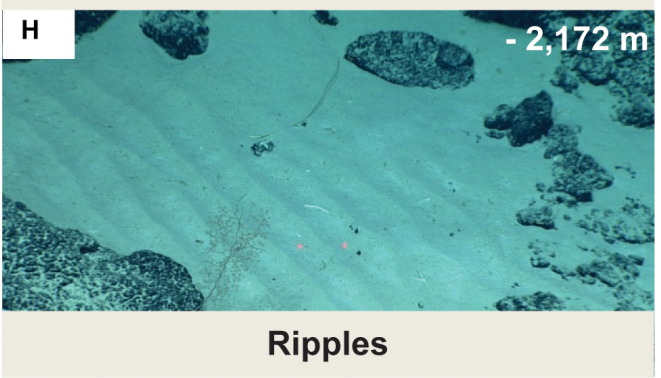

FIGURE 3 | Eight facies observed on the seafloor of the dive sites. (A) Ferromanganese-encrusted basaltic cobbles, (B) Ferromanganese-encrusted basaltic boulder, (C) Ferromanganese-encrusted basaltic slabs, (D) Coarse sands, (E) Living single Isididae, (F) Living Isididae thickets, (G) Coral debris, and (H) Ripples of coarse sediments between the basaltic boulders. Image courtesy of the NOAA's Office of Ocean Exploration and Research, Mountains in the Deep: Exploring the Central Pacific Basin.

since the Mid-Cretaceous. The current-removed sediment likely accumulates in drifts surrounding the Manihiki Plateau.

\section{Deep Ocean Currents Control on Isididae Distribution}

At both dive locations, Isididae colonize the ferromanganeseencrusted basaltic boulders and cobbles. The abundance of large slabs available in "Te Kawhiti" likely created favorable conditions for cold-water coral larvae to settle and colonize (Edinger et al., 2011; Thresher et al., 2014), although deep-water bamboo forests have been reported from muddy environments (de Moura Neves et al., 2015). The abundance of isidids coverage is markedly different at the two dive sites, likely the result of the different flow direction of the LCDW at each dive site. Isidids are suspension feeders and depend on current flow to deliver organic material to their polyps (Roark et al., 2005; Tracey et al., 2007; Hill et al., 2014). Current-facing ridge flanks are optimal for the interception of food particles, and coral colonies in this position experience higher survivorship (Dorschel et al., 2007; Correa et al., 2012). The "Te Tuku" site is on the leeward side of the current flow, while the site "Te Kawhiti" is exposed to the southward flowing current regime. As a result, isidid colonies flourish at "Te Kawhiti", reaching great heights forming thickets, while at site "Te Tuku," only individual isidids were observed. In areas of mobile sediments, no corals are present likely due to the 

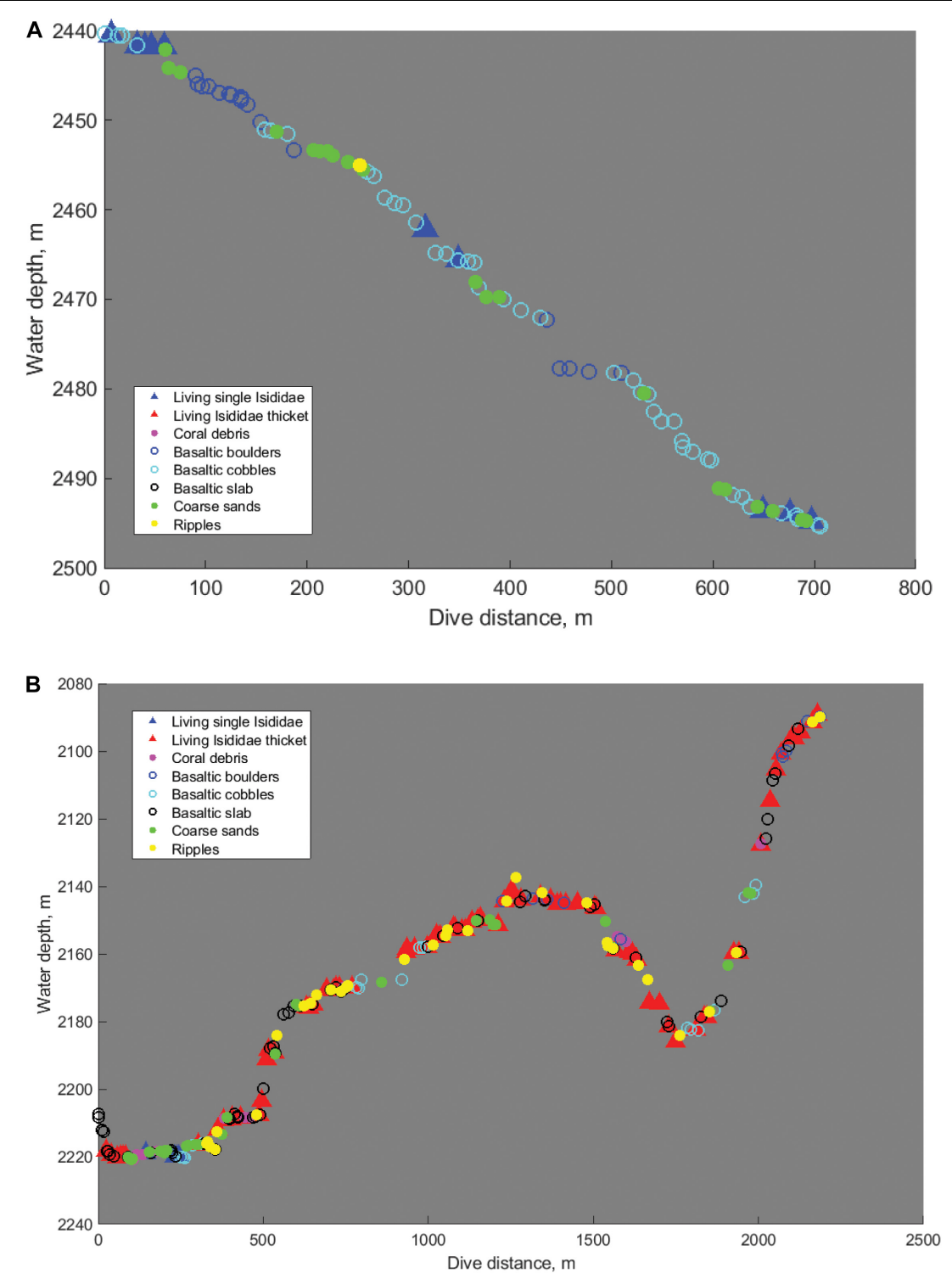

FIGURE 4 | Facies distribution along "Te Tuku" mesa (A) and "Te Kawhiti" ridges summit (B). Red and blue filled triangles represent the occurrence of single Isididae and Isididae thickets. No Isididae thickets and basaltic slabs were observed along "Te Tuku" dive. Fewer Isididae were observed at depths where coarse sands are dominant. The substrates for the Isididae are ferromanganese-encrusted basaltic boulders, cobbles, and slabs represented in circles. Green, yellow, and magenta dots represent coarse sands, ripples, and coral debris.

combined result of (1) a lack of a stable surface for coral larvae to settle and (2) exposure to stronger currents that inhibit the settling of the coral larvae.

\section{Isididae Growth Below the High-Mg Calcite Saturation Horizon}

The solubility of high-Mg calcite is similar to or slightly higher than that of aragonite (Morse et al., 2006); hence, these dive sites are $1-1.5 \mathrm{~km}$ below the probable HMCSH. Despite being located below the HMCSH, cold-water corals and other carbonate secreting organisms are abundant on the seamounts and ridges visited during the Central Pacific Basin expedition (EX1705). This is possible because isidids have an absolute low tolerance limit of about $40 \%$ undersaturation as suggested by Thresher et al. (2011). The outer layer of organic tissue protecting the skeleton of live corals, and food availability facilitates the growth of isidids in the low-carbonate conditions (Cohen and Holcomb, 2009; Sherwood et al., 2009; Thresher et al., 2011).

\section{CONCLUSION}

Two dives on volcanic mesa and ridges at $\sim 2,000-2,500 \mathrm{~m}$ water depth of the Northern Manihiki Plateau give insight into the influence of deep ocean currents on sediments and Isididae 
distribution. Direct evidence of persistent sweeping by the currents is given by the fact that the basaltic edifices do not exhibit pelagic drapes or remnants of old sediment cover, although they formed 125 million years ago and are subjected to pelagic sedimentation and carbonate sediment production by benthic organisms. As a result of non-deposition, ferromanganese crusts cover the basaltic cobbles, boulders, and slabs. Coarse sediments, however, accumulate in crevasses and depressions and record current activity and direction with asymmetric ripples.

The hard substrates and the currents enable cold-water corals to grow. Isidids abundance is related to the current strength with single isidids in the lee side of currents (as seen at "Te Tuku"), and thickets of isidids in the more current-exposed "Te Kawhiti" ridge summit. Here, the isidids flourish, although the sites are located below $\sim 2,000 \mathrm{~m}$ water depth and thus, below the $\mathrm{HMCSH}$, where the water masses are undersaturated in regards to high-Mg calcite. The growth of isidids on these dive sites indicates that water depths is not the factor of growth for this species. A reason for the abundant growth is the food availability through the bottom currents flow at the dive sites.

\section{DATA AVAILABILITY STATEMENT}

The datasets generated for this study are available on request to the corresponding author.

\section{AUTHOR CONTRIBUTIONS}

SB contributed to the conception and design of the study. KG contributed to the oceanography and cold-water corals' section.

\section{REFERENCES}

Batiza, R. (2001). Seamounts and off-ridge volcanism. Encycl. Ocean Sci. 5, 292304. doi: 10.1016/B978-012374473-9.00097-7

Bostock, H. C., Hayward, B. W., Neil, H. L., Currie, K. I., and Dunbar, G. B. (2011). Deep-water carbonate concentrations in the southwest Pacific. Deep. Res. I 58, 72-85. doi: 10.1016/j.dsr.2010.11.010

Boyer, T. P., Baranova, O. K., Coleman, C., Garcia, H. E., Grodsky, A., Locarnini, R. A., et al. (2018). World Ocean Database 2018. Asheville, NC: NOAA.

Cantwell, K., France, S., and Bohnenstiehl, D. (2017). Oceanographic data and information collected during the EX1705 American Samoa, Kingman/Palmyra, Jarvis (ROV \& Mapping) expedition on NOAA Ship OKEANOS EXPLORER in the Pacific Ocean from 2017-04-27 to 2017-05-19 (NCEI Accession 0163984). [ROV DIVE02 AND DIVE 03]. Asheville, NC: NOAA National Centers for Environmental Information.

Cohen, A. L., and Holcomb, M. (2009). Why corals care about acidification. Oceanography 22, 118-127.

Correa, T. B. S., Grasmueck, M., Eberli, G. P., Reed, J. K., Verwer, K., and Purkis, S. (2012). Variability of cold-water coral mounds in a high sediment input and tidal current regime. Straits of Florida. Sedimentology 59, 1278-1304. doi: 10.1111/j.1365-3091.2011.01306.x

de Moura Neves, B., Edinger, E. N., Hillaire-Marcel, C., Saucier, E. H., France, S. C., Treble, M. A., et al. (2015). Deep-water bamboo coral forests in a muddy Arctic environment. Mar. Biodivers. 45, 867-871. doi: 10.1007/s12526-0140291-7

Dorschel, B., Hebbeln, D., Foubert, A., White, M., and Wheeler, A. J. (2007). Hydrodynamics and cold-water coral facies distribution related to recent
GE contributed to concepts and all sections of the manuscript. $\mathrm{KC}$ contributed to the dataset and methods of the study.

\section{FUNDING}

EX1705 expedition was funded by the NOAA's Office of Ocean Exploration and Research. This organization also funded Kasey Cantwell via contract. Sara Bashah acknowledges financial support from the Schlumberger Foundation. Gregor Eberli was supported by contributions from industrial associates to the CSL - Center for Carbonate Research at the University of Miami. Kimberly Galvez received funds from a grant to Gregor Eberli.

\section{ACKNOWLEDGMENTS}

The authors thank the EX1705 Okeanos Explorer Program Manager, Craig Russell, and mapping lead, Michael White, from NOAA's Office of Ocean Exploration and Research for the help with the bathymetric data. The authors would also like to thank the science leads, Scott C. France from the University of Louisiana at Lafayette and Del Bohnenstiehl from the North Carolina State University, all EX1705 expedition members as well as the officers and crew of NOAA Ship Okeanos Explorer for the data used in the study. GE and SB thank Shirley Pomponi for inviting them to the Exploration Command Center and for the costs during their stay at the Harbor Branch Oceanographic Institute. The scientific input and stimulating discussions with her and Diva Amon helped clarify the scientific ideas.

sedimentary processes at Galway Mound west of Ireland. Mar. Geol. 244, 184-195. doi: 10.1016/j.margeo.2007.06.010

Edinger, E. N., Sherwood, O. A., Piper, D. J. W., Wareham, V. E., Baker, K. D., Gilkinson, K. D., et al. (2011). Geological features supporting deep-sea coral habitat in Atlantic Canada. Cont Shelf Res. 31, S69-S84. doi: 10.1016/j.csr.2010. 07.004

Feely, R. A., Sabine, C. L., Lee, K., Millero, F. J., Lamb, M. F., Greeley, D., et al. (2002). In situ calcium carbonate dissolution in the Pacific Ocean. Glob. Biogeochem. Cycles 16:91. doi: 10.1029/2002GB001866

France, S. C. (2007). Genetic analysis of bamboo corals (Cnidaria: Octocorallia: Isididae): does lack of colony branching distinguish Lepidisis from Keratoisis? Bull. Mar. Sci. 81, 323-333.

Grant, R. (1976). The marine fauna of New Zealand: Isididae (Octocorallia: Gorgonacea) from New Zealand and the Antarctic. Wellington: New Zealand Oceanographic Institute Memoir.

Hartin, C. A., Fine, R. A., Sloyan, B. M., Talley, L. D., Chereskin, T. K., and Happell, J. (2011). Formation rates of Subantarctic mode water and Antarctic intermediate water within the South Pacific. Deep Sea Res. I 58, 524-534. doi: 10.1016/j.dsr.2011.02.010

Heezen, B. C., Glass, B., and Menard, H. W. (1966). The manihiki plateau. Deep. Res. 13, 445-458.

Hill, T. M., Myrvold, C. R., Spero, H. J., and Guilderson, T. P. (2014). Evidence for benthic-pelagic food web coupling and carbon export from California margin bamboo coral archives. Biogeosciences 11, 3845-3854. doi: 10.5194/bg-11-38452014

Kawabe, M., and Fujio, S. (2010). Pacific ocean circulation based on observation. J. Oceanogr. 66, 389-403. doi: 10.1007/s10872-010-0034-8 
Kennedy, B. R. C., Cantwell, K., Malik, M., Kelley, C., Potter, J., Elliott, K. P., et al. (2019). The unknown and the unexplored: insights into the Pacific Deep Sea following NOAA CAPSTONE expeditions. Front. Mar. Sci. 6:180. doi: 10.3389/ fmars.2019.00480

Lyle, M., Gibbs, S., Moore, T. C., and Rea, D. K. (2007). Late Oligocene initiation of the Antarctic circumpolar current: evidence from the South Pacific. Geology 35, 691-694. doi: 10.1130/G23806A.1

Molina-Kescher, M., Hathorne, E. C., Osborne, A. H., Behrens, M. K., Pahnke, K., Kölling, M. et al. (2018). The influence of basaltic islands on the oceanic REE distribution: a case study from the tropical south pacific. Front. Mar. Sci. 5:50. doi: $10.3389 /$ fmars.2018.00050

Morse, J. W., Andersson, A. J., and Mackenzie, F. T. (2006). Initial responses of carbonate-rich shelf sediments to rising atmospheric pCO2 and "ocean acidification": role of high Mg-calcites. Geochim. Cosmochim. Acta 70, 58145830. doi: 10.1016/j.gca.2006.08.017

Noé, S. U., and Dullo, W.-C. (2006). Skeletal morphogenesis and growth mode of modern and fossil deep-water isidid gorgonians (Octocorallia) in the west Pacific (New Zealand and Sea of Okhotsk). Coral Reefs 25, 303-320.

Pietsch, R., and Uenzelmann-Neben, G. (2015). The Manihiki Plateau-A multistage volcanic emplacement history. Geochem. Geophys. Geosyst. 16, 2480 2498. doi: 10.1002/2015GC005852

Roark, E. B., Guilderson, T. P., Flood-Page, S., Dunbar, R. B., Ingram, B. L., Fallon, S. J., et al. (2005). Radiocarbon-based ages and growth rates of bamboo corals from the Gulf of Alaska. Geophys. Res. Lett. 32, 1-5. doi: 10.1029/ 2004GL021919

Rogers, A. D. (2013). Seamounts Project: An Ecosystem Approach to Management of Seamounts in the Southern Indian Ocean. Gland: IUCN, 60.

Sherwood, O. A., Thresher, R. E., Fallon, S. J., Davies, D. M., and Trull, T. W. (2009). Multi-century time-series of $15 \mathrm{~N}$ and $14 \mathrm{C}$ in bamboo corals from deep Tasmanian seamounts: evidence for stable oceanographic conditions. Mar. Ecol. Prog. Ser. 397, 209-218.

Stille, P. (1992). Nd-Sr isotope evidence for dramatic changes of paleocurrents in the Atlantic Ocean during the past 80 m.y. Geology 20, 387-390.

Stow, D. A. V., Hernández-Molina, F. J., Llave, E., Sayago-Gil, M., Díaz-del Río, V., and Branson, A. (2009). Bedform-velocity matrix: the estimation of bottom current velocity from bedform observations. Geology 37, 327-330. doi: 10.1130/ G25259A.1
Thresher, R., Althaus, F., Adkins, J., Gowlett-Holmes, K., Alderslade, P., Dowdney, J., et al. (2014). Strong depth-related zonation of megabenthos on a rocky continental margin ( 700-4000 m) off Southern Tasmania. Australia. PLoS One 9:e85872. doi: 10.1371/journal.pone.0085872

Thresher, R. E., Tilbrook, B., Fallon, S., Wilson, N. C., and Adkins, J. (2011). Effects of chronic low carbonate saturation levels on the distribution, growth and skeletal chemistry of deep-sea corals and other seamount megabenthos. Mar. Ecol. Prog. Ser. 442, 87-96. doi: 10.3354/meps09400

Timm, C., Hoernle, K., Werner, R., Hauff, F., den Bogaard, P., van Michael, P., et al. (2011). Age and geochemistry of the oceanic Manihiki Plateau. SW Pacific: new evidence for a plume origin. Earth Planet. Sci. Lett. 304, 135-146. doi: 10.1016/j.epsl.2011.01.025

Tomczak, M., and Godfrey, J. S. (2003). Regional Oceanography: An Introduction. Delhi: Daya Publishing House.

Tracey, D. M., Neil, H., Marriott, P., Andrews, A. H., Cailliet, G. M., and Sanchez, J. A. (2007). Age and growth of two genera of deep-sea bamboo corals (Family Isididae) in New Zealand waters. Bull. Mar. Sci. 81, 393-408.

Werner, R., Nürnberg, D., Hauff, F., and Shipboard scientific Party (2013). RV Sonne Fahrtbericht / Cruise Report SO225 Manihiki II Leg 2 The Manihiki Plateau - Origin, Structure and Effects of Oceanic Plateaus and Pleistocene Dynamic of the West Pacific Warm Water Pool. Germany: Kiel, doi: 10.3289/ GEOMAR_REP_NS_7_2013

Winterer, E. L., Lonsdale, P. F., Matthews, J. L., and Rosendahl, B. R. (1974). Structure and acoustic stratigraphy of the Manihiki Plateau. Deep. Res. 21, 793-814. doi: 10.1016/0011-7471(74)90001-1

Conflict of Interest: The authors declare that the research was conducted in the absence of any commercial or financial relationships that could be construed as a potential conflict of interest.

Copyright (c) 2020 Bashah, Galvez, Eberli and Cantwell. This is an open-access article distributed under the terms of the Creative Commons Attribution License (CC BY). The use, distribution or reproduction in other forums is permitted, provided the original author(s) and the copyright owner(s) are credited and that the original publication in this journal is cited, in accordance with accepted academic practice. No use, distribution or reproduction is permitted which does not comply with these terms. 